Endocrinol. Japon. 1985, 32 (5), 673-680

\title{
The Inter- and Intra-Subject Variabilities of Plasma GH Response to Human Growth Hormone-Releasing Hormone (1-44) $\mathrm{NH}_{2}$ in Men
}

\author{
Mari HOTTA, Tamotsu SHIBASAKI, Akitsugu MASUDA, Toshihiro \\ IMAKI, ICHIJI WAKABAYASHI ${ }^{1}$, HIROSHI DEMURA, \\ Nicholas LING ${ }^{2)}$ and KAZUO SHIZUME \\ Department of Medicine, Institute of Clinical Endocrinology Tokyo Women's \\ Medical college 10 Kawada-cho, Ichigaya, Shinjuku-ku, Tokyo 162 \\ 1) Department of Medicine, Nippon Medical School, Sendagi 1-1-5 Bunkyo-ku, \\ Tokyo 113 \\ 2) Laboratories for Neuroendocrinology, The Salk Institute for Biological Studies \\ La Jolla, California 92037, U. S. A.
}

\begin{abstract}
The effects of intravenously given human growth hormone-releasing hormone (1-44) $\mathrm{NH}_{2}$ (hGRH-44) on growth hormone (GH) secretion were studied in normal men.

A wide variability of intersubject GH response to hGRH-44 was observed. The peak plasma GH levels in response to 50, 100 and $200 \mu \mathrm{g}$ hGRH-44 in 7 normal men were $9.1 \pm 3.2 \mathrm{ng} / \mathrm{ml}($ Mean $+\mathrm{SEM}), 19.3 \pm 3.3 \mathrm{ng} / \mathrm{ml}$ and $22.4 \pm 4.0$ $\mathrm{ng} / \mathrm{ml}$, respectively. Both the mean peak values for plasma $\mathrm{GH}$ response to 100 and $200 \mu \mathrm{g}$ were significantly greater than that for $50 \mu \mathrm{g}$ hGRH-44 injection $(\mathrm{p}<0.01)$, although there was no significant difference of the mean peak plasma GH values and mean concentrations at each time point, except for those at $120 \mathrm{~min}$, when 100 or $200 \mu \mathrm{g}$ hGRH-44 was administered. A significant difference in the mean amount of plasma GH secreted in response to hGRH-44 was observed only between 50 and $200 \mu \mathrm{g}$ hGRH-44 injection $(\mathrm{p}<0.01)$. Furthermore, a dose-related plasma GH increase in response to hGRH-44 was not always observed in each subject.

In contrast to the wide intersubject variability, the difference among responses of plasma GH to $100 \mu \mathrm{g}$ or $200 \mu \mathrm{g}$ of hGRH-44 given at multiple times separated by intervals of at least 1 week in each individual was relatively small.

These results suggest that the wide intersubject variability could cause no dose-related GH response to hGRH-44 in doses of 50,100 and $200 \mu \mathrm{g}$ and that the intrasubject variability was small enough to evaluate the GH secretion by a single hGRH-44 injection, a procedure not adopted before.
\end{abstract}

Three peptides with growth hormonereleasing activity were originally isolated from human pancreas tumors that had

Received May 2, 1985 caused acromegaly. Amino acid sequence determination showed that they were closely related in structure and contained 37, 40 and 44 residues, respectively (Guillemin et al., 1982 ; Rivier et al., 1982). Recently human 
hypothalamic growth hormone-releasing hormones (hGRHs) were shown to be identical to 44 and 40 residue $\mathrm{GH}$ releasing peptides isolated from pancreas tumors (Ling et al., 1984).

Human GRHs have been demonstrated to be specific and potent secretagogues for GH release in normal human (Thorner et al., Gelato et al., 1983; Shibasaki et al., 1984a, Vance et al., Gelato et al., 1984). However, the dose-related plasma $\mathrm{GH}$ response to hGRH injection was still controversial (Rosenthal et al., Wood et al., 1983; Vance et al., Gelato et al., 1984). These papers indicated the intersubject variability of plasma GH response to hGRH (Thorner et al., Gelato et al., Rosenthal et al., Wood et al., 1983, Vance et al., 1984), but there was no report in which the intrasubject variability of plasma $\mathrm{GH}$ response to hGRH was studied. This prompted us to examine intra and intersubject variabilities of plasma $\mathrm{GH}$ response to a single dose of hGRH-44 in healthy men in order to confirm the reliability of hGRH injection test in evaluating $\mathrm{GH}$ secretion.

\section{Subjects and Methods}

\section{Human subjects}

Thirieen healthy men aged 21-41 years and weighing $48-68 \mathrm{~kg}$ were chosen for this study.

Informed consent was obtained from each subject before this study. The experimental protocol for this test was reviewed and approved by our departmental review committee of the Tokyo Women's Medical College.

\section{GRH test}

The GRH test was described earlier in our papers (Shibasaki et al., 1984a ; Shibasaki et al., 1984b ; Masuda et al., Imaki et al., 1985). Seven volunteers (Cases 1-7) were administered 50, 100 and $200 \mu \mathrm{g} \mathrm{hGRH}-44$ and another five (Cases 812) were injected with two doses of hGRH-44, 50,100 or $200 \mu \mathrm{g}$, at different times. Furthermore, five subjects (Cases 1, 2, 4, 5, and 14)
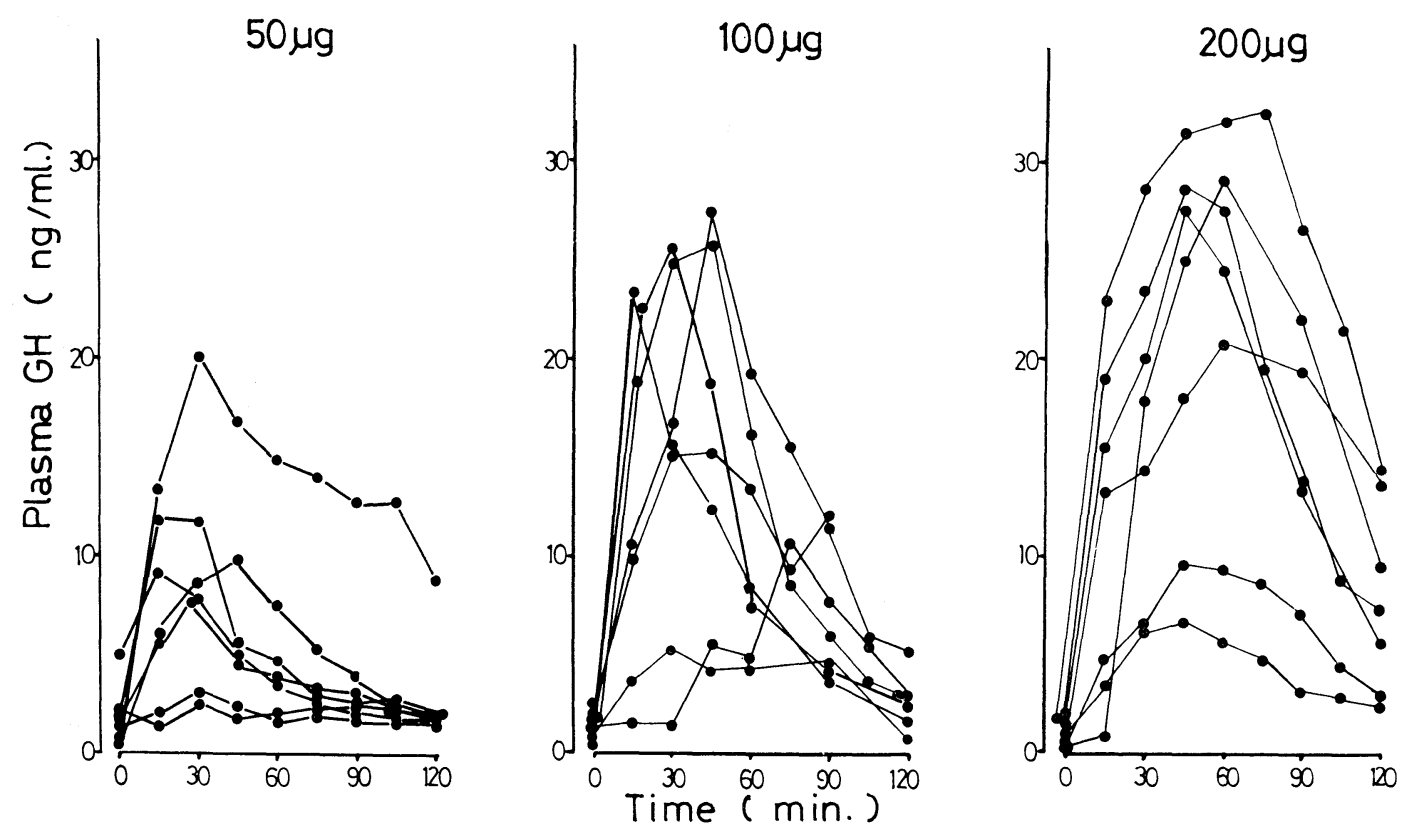

Fig. 1. Response of plasma GH to intravenously administered hGRH-44 in doses of 50,100 and $200 \mu \mathrm{g}$ in 7 normal men. 
participated in a $100 \mu \mathrm{g}$ hGRH-44 test and six subjects (Cases 1, 2, 4, 8, 9, and 13) received a $200 \mu \mathrm{g}$ hGRH-44 injection twice or three times separated by intervals of at least 1 week.

\section{Radioimmunoassay for $G H$}

Radioimmunoassay (RIA) for plasma $\mathrm{GH}$ was performed with human $\mathrm{GH}$ standard and anti-human $\mathrm{GH}$ serum generously supplied by NIADDKD's Pituitary Hormone Distribution Program. The intra- and inter-assay coefficients of variation were $6.5 \%$ and $7.9 \%$, respectively. The minimal detectable dose was $70-80 \mathrm{pg} /$ tube.

\section{Peptides}

The hGRH-44 in this study was synthesized by solid-phase methodology as described earlier (Ling et al., 1984). The synthetic products have the correct amino acid composition and a purity level shown by reverse-phase high performance liquid chromatography to be higher than $95 \%$.

\section{Results}

Figure 1 shows the responses of plasma $\mathrm{GH}$ to the intravenously administered 50, 100 and $200 \mu \mathrm{g}$ hGRH-44 in seven healthy men aged 22-31 years (mean 26) and weighing $57-69 \mathrm{~kg}$ (mean 64). It was apparent that there was a wide variation in $\mathrm{GH}$ response to the same dose of hGRH44 in normal subjects. After the administration of $50 \mu \mathrm{g}$ hGRH-44, the plasma GH increased from the basal value of $1.8 \pm 0.6$ $\mathrm{ng} / \mathrm{ml}$ (Mean \pm SEM) to the peak value of $9.1 \pm 3.2 \mathrm{ng} / \mathrm{ml}$ in the first $15-30 \mathrm{~min}$. However, there were two volunteers in their twenties whose plasma $\mathrm{GH}$ failed to show a significant increase after the $50 \mu \mathrm{g}$ hGRH44 injection. One hundred $\mu \mathrm{ghGRH}-44$ induced an increase in the plasma $\mathrm{GH}$ level from $1.4 \pm 0.3 \mathrm{ng} / \mathrm{ml}$ to $19.0 \pm 3.3 \mathrm{ng} / \mathrm{ml}$ at $15-45 \mathrm{~min}$ after the injection. The plasma GH level rose from the basal levels of $1.0 \pm 0.3 \mathrm{ng} / \mathrm{ml}$ to the peak level of 22.4 $\pm 4.0 \mathrm{ng} / \mathrm{ml}$ at $45-60 \mathrm{~min}$ after the administration of $200 \mu \mathrm{g}$ hGRH-44. Both the mean peak values of plasma $\mathrm{GH}$ in res-

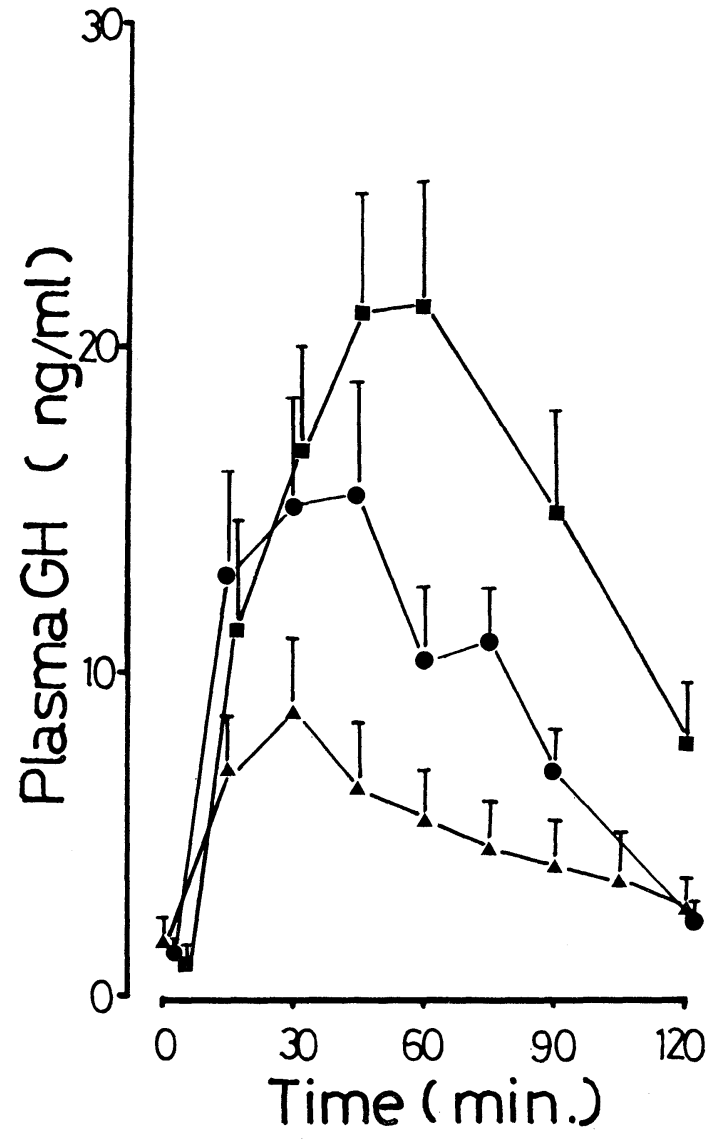

Fig. 2. Mean plasma GH concentrations in response to 50,100 and $200 \mu \mathrm{g}$ hGRH-44 in 7 normal men.

A-A $50 \mu \mathrm{g}, \bullet-\bullet 100 \mu \mathrm{g}, \quad \boldsymbol{\square}-\mathbf{\square} 200 \mu \mathrm{g}$.

ponse to 100 and $200 \mu \mathrm{g}$ hGRH-44 were significantly greater than that in the $50 \mu \mathrm{g}$ hGRH-44 injection $(\mathrm{p}<0.01)$. However, there was no significant difference between the plasma GH peak values for 100 and $200 \mu \mathrm{g}$ hGRH-44 administration.

The mean plasma $\mathrm{GH}$ changes after the injection of each dose of hGRH-44 are shown in Figure 2. There was no significant difference between plasma GH levels for 50 and $100 \mu \mathrm{g}$ hGRH-44 administration at each time point, whereas each mean plasma $\mathrm{GH}$ value at $30(\mathrm{p}<0.05), 45(\mathrm{p}<0.005)$, 

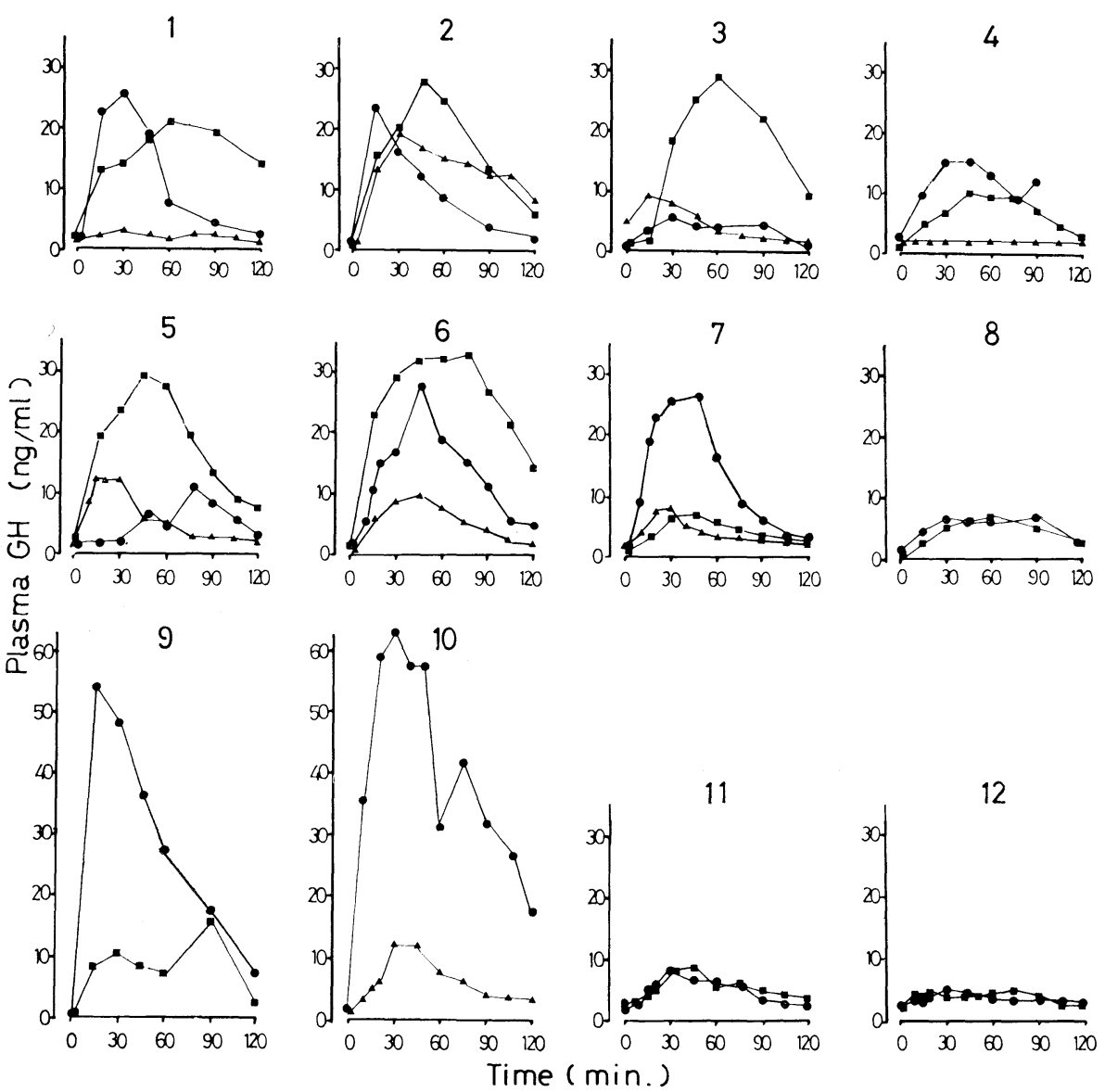

Fig. 3. Each plasma GH response after hGRH-44 injection in doses of 50,100 and $200 \mu \mathrm{g}$ in 12 normal men.

$60(\mathrm{p}<0.005)$ and $90 \min (\mathrm{p}<0.05)$ after the $200 \mu \mathrm{g}$ hGRH-44 injection was significantly higher than that in response to 50 $\mu \mathrm{g}$ hGRH-44. A significant difference in the mean plasma $\mathrm{GH}$ concentrations was obtained only at $120 \mathrm{~min}(\mathrm{p}<0.005)$ between 100 and $200 \mu \mathrm{g}$ hGRH-44 administration.

The mean total amounts of plasma $\mathrm{GH}$ response to 50,100 and $200 \mu \mathrm{g}$ hGRH-44 for $2 \mathrm{hr}$ were $446.1 \pm 207.1 \mathrm{ng} \cdot \mathrm{min} / \mathrm{ml}$ (Mean \pm SEM), $982.4 \pm 174.2$ and $1683.4 \pm 304.7$, respectively. There was a significant difference in the mean total amounts of plasma $\mathrm{GH}$ only between the administration of 50 $\mu \mathrm{g}$ and $200 \mu \mathrm{g}$ hGRH-44.

The plasma $\mathrm{GH}$ responses in 7 normal volunteers (No. 1-7) who were injected with 50, 100 and $200 \mu \mathrm{g} \mathrm{hGRH-44} \mathrm{and} \mathrm{in} \mathrm{the}$ other 5 healthy volunteers (No. 8-12) administered two doses of hGRH-44 are demonstrated in Figure 3. The dose-related plasma $\mathrm{GH}$ increase in response to hGRH44 was not always observed in each subject. Two subjects in their twenties (No. 1 and 4) showed no significant increase due to 50 $\mu \mathrm{g}$ hGRH-44, though they had considerable plasma $\mathrm{GH}$ responses after both 100 and $200 \mu \mathrm{g}$ hGRH-44 administration. In the 

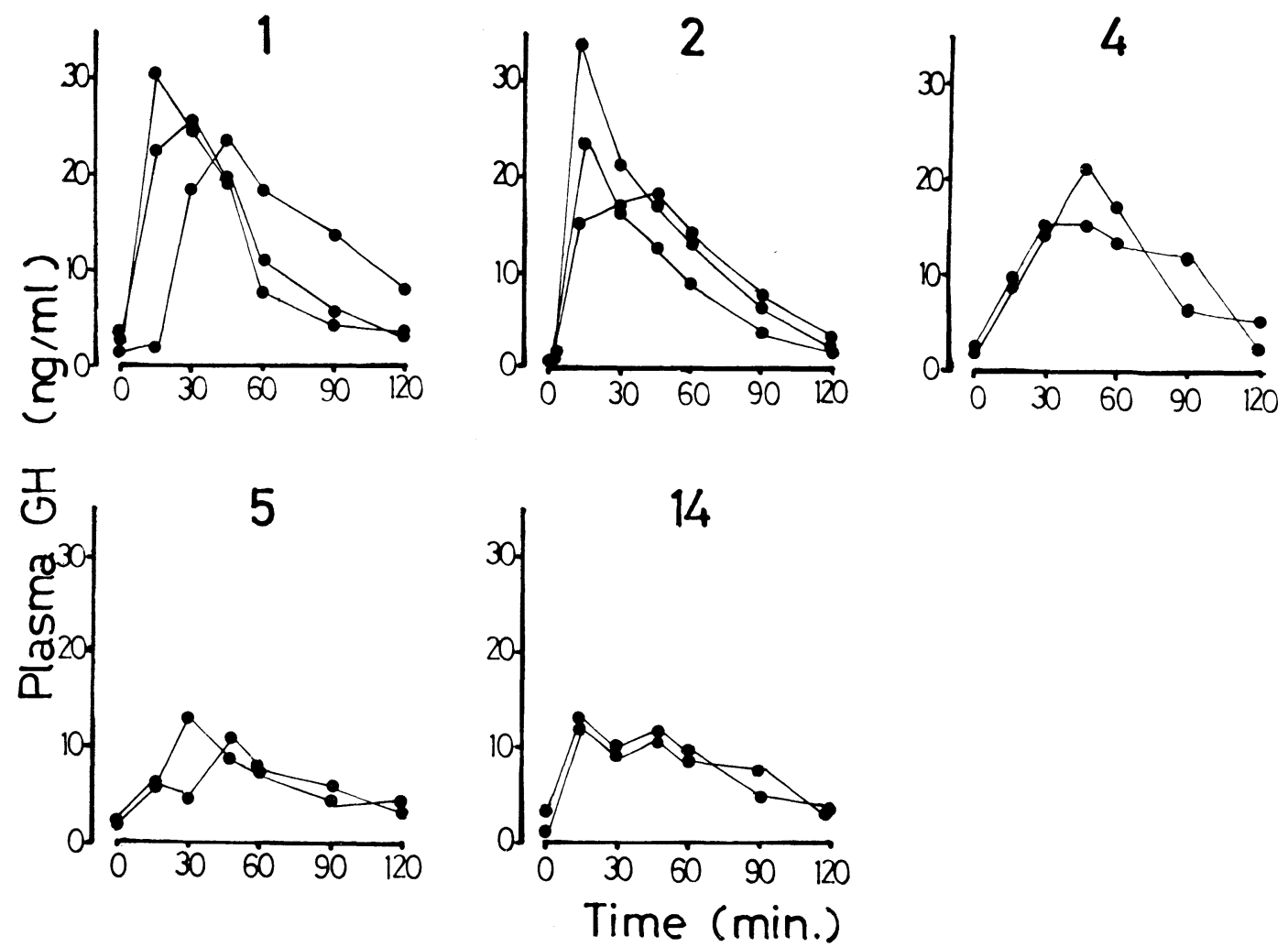

Fig. 4. Plasma GH responses in two or three $100 \mu \mathrm{g}$ hGRH-44 tests in 5 normal men.

subject (No. 12) aged 41 years the plasma $\mathrm{GH}$ level did not rise in response to either 100 or $200 \mu \mathrm{g}$ hGRH-44.

The reproducibility of a subject's plasma $\mathrm{GH}$ response to intravenously administered hGRH-44 is illustrated in Figures 4 and 5. Five volunteers participated in the $100 \mu \mathrm{g}$ hGRH test twice or three times at intervals of at least a week. Although their plasma $\mathrm{GH}$ peak values in response to $100 \mu \mathrm{g}$ hGRH-44 were different in some cases, the amounts of plasma $\mathrm{GH}$ increase were alike in all subjects. Six subjects received $200 \mu \mathrm{g}$ of hGRH-44 twice or three times at intervals of at least a week. Plasma GH responses to hGRH-44 were similar in four subjects (Cases 1, 4, 8 and 9). Although the other two volunteers (Cases 2 and 13) showed varying plasma $\mathrm{GH}$ responses with different peak values, the response patterns in all subjects were similar.

Among all these normal subjects there were no significant changes in plasma $\mathrm{LH}$, FSH, TSH, PRL, cortisol or glucose levels following the administration of hGRH-44 (data not shown).

Almost all subjects felt flushing and a warm sensation in the face and neck between $30 \mathrm{sec}$ and $5 \mathrm{~min}$ after injection of hGRH-44 at a dose of $100 \mu \mathrm{g}$ or higher and had observable facial and neck flushing within 2 min of administration which diminished in approximately $10 \mathrm{~min}$. Thermography detected a $1^{\circ} \mathrm{C}$ increase in temperature in a subject's facial surface in response to hGRH44 (data not shown). However, the blood pressure and pulse rate were unchanged. There was no abnormality in the complete 

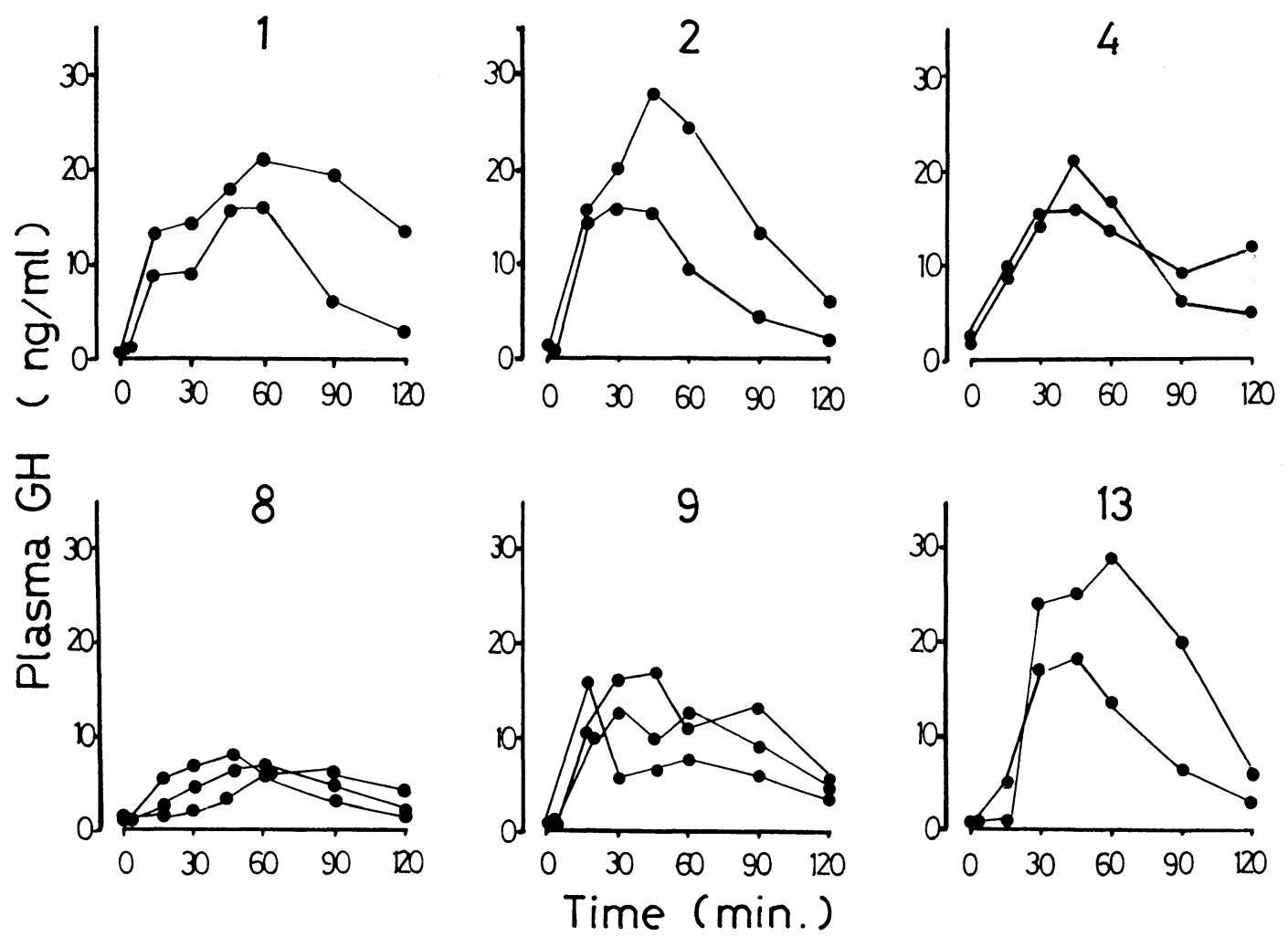

Fig. 5. Plasma GH Responses in two or three of $200 \mu \mathrm{g}$ hGRH-44 tests in 6 normal men.

blood cell count, general urinalysis or blood chemistry one week after a hGRH test in any of the subjects (data not shown).

\section{Discussion}

The intravenous administration of doses of 50,100 and $200 \mu \mathrm{g}$ of hGRH-44 were performed in 7 normal subjects. These doses of 50,100 and $200 \mu \mathrm{g}$ in our study corresponded to about $0.8,1.6$ and $3.0 \mu \mathrm{g} /$ $\mathrm{kg}$ body weight, respectively. We observed that there was a significant difference between the peak plasma $\mathrm{GH}$ values in response to $50 \mu \mathrm{g}$ hGRH-44 and those evoked by 100 or $200 \mu \mathrm{g} \mathrm{hGRH}-44$ and that the mean plasma GH level at $120 \mathrm{~min}$ after the injection of $200 \mu \mathrm{g}$ hGRH-44 was significantly higher than that following $100 \mu \mathrm{g} \mathrm{hGRH}$ 44 , although there was no significant difference between the peak values of plasma GH for 100 and $200 \mu \mathrm{g}$ hGRH-44 administration. Concerning the dose-related $\mathrm{GH}$ response to the hGRH-44 injection, Rosenthal et al. (1983) reported that no significant relationship between the peak plasma GH levels and the dose of hGRH-44 could be demonstrated by using $0.5,5$ and $10 \mu \mathrm{g} / \mathrm{kg}$ body weight hGRH-44. Vance et al. (1984) concluded that no dose-response relationship between $0.1,0.33,1.0,3.3$ and $10 \mu \mathrm{g} / \mathrm{kg}$ body weight of hGRH-40 was found and these results might be caused by the considerable difference in response among subjects. On the other hand, Wood et al. (1983) indicated that hGRH-44 in doses of 10,30 and $100 \mu \mathrm{g}$ dose-dependently stimu- 
lated the release of $\mathrm{GH}$. These results therefore suggest that the dose-related $\mathrm{GH}$ response to hGRH is observed only when the intersubject variation in plasma $\mathrm{GH}$ response is small and the dose of hGRH is less than $100 \mu \mathrm{g}$.

The considerable intersubject variation in plasma GH response after the hGRH-44 injection was demonstrated in this study as in others (Thorner et al., Gelato et al., Rosenthal et al., Wood et al., 1983; Vance et al., 1984). The peak plasma GH values caused by $50 \mu \mathrm{g}$ hGRH-44 in 8 subjects aged below forty years ranged from 2.3 $\mathrm{ng} / \mathrm{ml}$ to $20 \mathrm{ng} / \mathrm{ml}$ and there were 2 nonresponders, who showed a considerable $\mathrm{GH}$ increase in response to 100 and $200 \mu \mathrm{g}$ hGRH-44. Thorner et al. (1983) also reported that 2 subjects out of the 6 normal in their twenties did not show a significant response of plasma $\mathrm{GH}$ after the $1 \mu \mathrm{g} / \mathrm{kg}$ body weight hGRH-40 injection, but had a normal GH response to insulin-induced hypoglycemia. So these results indicate that $50 \mu \mathrm{g}$ or $1 \mu \mathrm{g} / \mathrm{kg}$ body weight hGRH was not enough to fully stimulate GH secretion in these young non-responders, who might have a decreased responsiveness of the pituitary to hGRH or increased somatostatin secretion. Therefore, the injection of at least $100 \mu \mathrm{g} \mathrm{hGRH}-44$ is recommended in order to evaluate the GH secretion. In one subject (Case 12) aged 41 years neither $100 \mu \mathrm{g}$ nor $200 \mu \mathrm{g}$ hGRH-44 elicited a response in plasma GH. Since our previous paper (Shibasaki et al., 1984a) indicated the existence of an age-related decrease in plasma GH response to hGRH-44 in men, especially in men over forty years old, the absence of plasma $\mathrm{GH}$ response in this subject (Case 12) might be due to the effect of aging.

In this study we demonstrated not only considerable intersubject variation but also a small intrasubject variation in hGRH-44induced-GH secretion in normal subjects. The responses of plasma GH to hGRH-44 administration in doses of $100 \mu \mathrm{g}$ and 200 $\mu \mathrm{g}$ showed similar patterns of plasma $\mathrm{GH}$ secretion in each case. It can be therefore concluded from this study that a single injection of hGRH-44 in a dose of at least 100 $\mu \mathrm{g}$ is reliable enough to determine whether a response of plasma GH secretion is obtained or not.

\section{Acknowledgements}

The research was supported by a grant from the Japanese Ministry of Education, Science and Culture as well as NIH grants HD-09690 and AM-18811 from the U.S.A. We thank Drs. Ihara and Minami, Nippon Medical School, for their cooperation and Miss $\mathrm{N}$. Inoue for secretarial assistance.

\section{References}

Gelato, M. C., O. Pescovitz, F. Cassorla, L. Loriaux and G. R. Merriam (1983). Effects of a growth hormone releasing factor in man. J. Clin. Endocrinol. Metab. 57, 674-676.

Gelato, M. C., D. H. Pescovitz, F. Cassorla, D. L. Loriaux and G. R. Merriam (1984). Doseresponse relationship for the effects on growth hormone-releasing factor-(1-44)- $\mathrm{NH}_{2}$ in young adult men and women. J. Clin. Endocrinol. Metab. 59, 197-201.

Guillemin, R., P. Brazeau, P. Böhlen, F. Esch, N. Ling and W. B. Wehrenberg (1982). Growth hormone-releasing factor from a human pancreatic tumor that caused acromegaly. Science 218, 585-587.

Imaki, T., T. Shibasaki, K. Shizume, A. Masuda, M. Hotta, Y. Kiyosawa, K. Jibiki, H. Demura, T. Tsushima and N. Ling (1985). The effect of free fatty acids on growth hormone (GH)releasing hormone-mediated GH secretion in man. J. Clin. Endocrinol. Metab. 60, 290-293.

Ling, N., F. Esch, P. Böhlen, P. Brazeau, W. B. Wehrenberg and R. Guillemin (1984). Isolation, primary structure and synthesis of human hypothalamic somatocrinin: Growth hormonereleasing factor. Proc. Nath. Acad. Sci. U.S.A. 81, 4302-4306

Masuda, A., T. Shibasaki, M. Nakahara, T. Imaki, Y. Kiyosawa, K. Jibiki, H. Demura, 
K. Shizume and N. Ling (1985). The effect of glucose on growth hormone (GH)-releasing hormone-mediated $\mathrm{GH}$ secretion in man. $J$. Clin. Endocrinol. Metab. 60, 523-526.

Rivier, J., J. Spiess, M. O. Thorner and W. W. Vale (1982). Characterization of a growth hormone-releasing factor from a human pancreatic islet cell tumor. Nature 300, 276-278.

Rosenthal S. M., E. A. Schriock, S. L. Kaplan, R. Guillemin and M. M. Grumback (1983). Synthetic human pancreas growth hormonereleasing factor (hp GRF 1-44- $\mathrm{NH}_{2}$ ) simulated growth hormone secretion in normal men. $J$. Clin. Endocrinol. Metab. 57, 677-679.

Shibasaki T., K. Shizume, M. Nakahara, A. Masuda, K. Jibiki, H. Demura, I. Wakabayashi and N. Ling (1984a). Age-related changes in plasma growth hormone response to growth hormone-releasing factor in man. J. Clin. Endocrinol. Metab. 58, 212-214

Shibasaki T., K. Shizume, A. Masuda, M. Nakahara, N. Hizuka, M. Miyakawa, K. Takano, H. Demura, I. Wakabayashi and N. Ling (1984b). Plasma growth hormone response to growth hormone-releasing factor in acromegalic patients. J. Clin. Endocrinol. Metab. 58, 215217.

Thorner, M. O., J. Rivier, J. Spiess, J. L. Borges M. L. Vance, S. R. Bloom, A. O. Rogol, H. J. Cronin, D. L. Kaiser, W. S. Evance, J. D. Webster, R. M. MacLord and W. Vale (1983). Human pancreatic growth hormone-releasing factor selectively stimulates growth-hormone secretion in man. Lancet 1, 24-28.

Vance, M. L., J. L. C. Borges, D. L. Kaiser, W. S. Evans, R. Furlanetto, J. L. Thominet, L. A. Frohman, A. D. Rogol, R. M. MacLord, S. Bloom, J. Rivier, W. Vale and M. O. Thorner (1984). Human pancreatic tumor growth hormone-releasing factor: Dose-response relationships in normal man. J. Clin. Endocrinol. Metab. 58, 838-844.

Wood, S. M., J. L. C. Ch'ng, E. F. Adams, J. D. Webster, G. F. Joplin, K. Mashiter and S. R. Bloom (1983). Abnormalities of growth hormone releasing in response to human pancreatic growth hormone releasing factor (GRF (1-44)) in acromegaly and hypopituitarism. Br. Med. J. 286, 1687-1691. 